\title{
Combining Prebiotic and Mixture of Freeze Dried Probiotics to Develop Synbiotics that Induce Apoptosis in Human Colon Tumor Cells
}

\author{
Wafaa F. Mohamed", Omar Al. Rabeea*, Hala M. Abu Shady* and Hebat Allah \\ I. Youssef \\ Microbiology Department, Ain Shams University Specialized Hospital and \\ *Microbiology Department,Faculty of Science, Ain Shams University, Cairo. Egypt.
}

\begin{abstract}
N THE PRESENT study, we first aimed to select some potential anti-cancer probiotics in vitro. Using the inulin fermentation product by the selected five probiotic bacteria (Lactobacillus paraplantarum strain $\mathrm{S} 143$, L. pentosus strain $\mathrm{P} 2-3$, L. plantarum strain J12, L.gasseri strain F. and L.reuteri strain IRT), Caco-2 cells were exposed to $50 \%$ filtrate supernatant of each probiotic bacteria after $24 \mathrm{~h}$ of incubation. Results showed that inulin fermentation product of the selected probiotics cause apoptosis in the Caco-2 cell line. Also, the viability of the freezedried powders of the five probiotics using skimmed milk as cryoprotectant was followed up for 12 weeks of storage at refrigerated conditions and also at room temperature. Results proved that lyophilized powders showed slight decrease in their viable count during storage both at room and refrigerated temperatures. This would ensure a good cell concentration for at least 3 months to be administered as a probiotic and would guarantee the long-term delivery of sufficient active, viable, and functional cultures.
\end{abstract}

Keywords: Probiotic, Mixture, Freeze dried, Synbiotic, Apoptosis and Tumor.

\section{Introduction}

Probiotics are live microorganism which, when consumed in sufficient amounts, provide a health benefits to the host (FAO/WHO, 2006). Generally regarded as safe (GRAS) organisms, lactic acid bacteria (LAB) have become the most widely used probiotics for medicine and food production. As probiotics, firstly, the microorganisms must be non-pathogenic and non-toxigenic; secondly, they should withstand external and internal environments, including gastric acid and bile salts. In addition, the adhesive ability of LAB is a primary consideration in the selection of probiotics (Saad et al., 2013).

Lactic acid bacteria together with bifidobacteria are most investigated probiotics since decades. The uniqueness of LAB is that they provide several health benefits as well as they are involved in food fermentations (Abushelaibi et al., 2017). Several criteria have been used to consider new LAB isolates as probiotic including tolerance to acid and bile conditions, cholesterol lowering potential, ability to hydrolyze bile salt, ability to possess antimicrobial properties, and able to survive during the fermentation process (Vijaya Kumar et al., 2015).

Based on the aforementioned, administration of beneficial microorganisms (called probiotics) or prebiotics (non-digestible ingredients of food that, when adiminsterd in sufficient amounts, selectively stimulate the growth and/or activity of one or a few number of health promoting bacteria in the colon) represents a promising approach for treating several gastrointestinal alterations and can have many beneficial effects on the body (Buigues et al., 2016).

Many recent publications have reviewed the role of probiotics, prebiotic and Synbiotics in Colorectal cancer (Orlando \& Russo, 2013). Colon cancer is the third most common cancer worldwide, with high morbidity and mortality (Haggar \& Boushey, 2009). world wide deaths from colon cancer have increased from 608,000 in 2008 to 694,000 in 2012 (WHO, 2014).

"Corresponding author email: wafaa3010@yahoo.com

DOI : 10.21608/ejm.2017.1272.1024

(C)2017 National Information and Documentation Center (NIDOC) 
Colorectal cancer (CRC) is a well-defined series of sequences caused by mutations, activations, and deletions of oncogenes and tumor suppressor genes leading to adenoma/carcinoma (Commane et al., 2005). Epidemiological, experimental, case, studies have shown a strong ability of mutagens to induce cancer (Biondi et al., 2012). CRC is influenced by environmental factors such as, diet and dietary habits, physical inactivity, consumption of tobacco and other occupational hazards (Stewart \& Kleihues, 2003). Food carcinogens produced during cooking at high temperatures and air pollution include, polycyclic aromatic hydrocarbons (PAH), heterocyclic amines (HCA), N-nitroso compounds (NOC), mycotoxins (aflatoxins) and acrylamide that represents a potential risk factors for CRC and other cancer types (Cross et al., 2010).

Treatments include either single or combination therapies such as chemotherapy, radiation, surgery, or biologically targeted management (Jemal et al., 2006). However, these therapies are less effective during metastasis, therefore prevention and early detection are key factors for reducing the risk of coloncancer (WHO, 2014). Recent attention has been focused on increasing dietary intake of probiotic and fibers (Globocan, 2012). LAB and their products of fermentation are claimed to be antimutagenic and Anticarcinogenic (Ljungh \& Wadström, 2006). Fermentation supernatant fractions of inulin showed a significant growth-inhibition and apoptosis induction in the human colon cancer cells (Munjal et al., 2009). The consumption of synbiotics, a mixture of probiotics and non digestible constituents such as dietary fiber, has been reported to reduce the risk of colon cancer (Steina et al, 2012). It is generally believed that probiotics act via alteration of the intestinal microflora, enhancement of the host's immune response, cell cycle arrest, promotion of apoptosis and induction of short-chain fatty acid (SCFA) production (Faghfoori et al., 2015). In addition, the ability of probiotic cells to adhere to the intestinal mucosa is a critical parameter to probiotic action. It has been shown that specific probiotic strains exert anti-proliferative effects via synergic actions between adhesion to colon cancer cells and production of short-chain fatty acids, mainly butyric and propionic acids (Thirabunyanon \& Hongwittayakorn, 2013).

The present study was aimed for the production of gelatin capsules containing the prebiotic inulin and freeze-dried mixture of synergistic probiotic bacteria capable of induction of apoptosis of colorectal cancer cell line and studying the survival of the freeze-dried powders of the probiotics during a 3 months storage period.

\section{$\underline{\text { Materials and Methods }}$}

\section{Selection of Inulin fermenting $L A B$}

In a previous study 42 isolates of $L A B$ bacteria have been tested for their probiotic potential, including; tolerance to simulated gastric and intestinal juices, antibiotic resistance, antagonistic activity toward some pathogenic bacteria and adhesion to Caco-2 cell line. The isolates with desirable characters have been selected for this study.

The obtained isolates were tested for their ability to utilize inulin as follows: MRS broth without any sugar (basal MRS) containing $40 \mathrm{mg} / \mathrm{L}$ of bromcresol purple was prepared and autoclaved. The inulin sugar solution was prepared, sterilized through a syringe filter $(0.22$ $\mu \mathrm{m}$ pore size) and added to the sterile medium to obtain the concentration of $10 \mathrm{~g} /$ liter. Isolates were activated in $10 \mathrm{ml}$ MRS medium and incubated at $37^{\circ} \mathrm{C}$ for $24 \mathrm{~h}$. Then, they were centrifuged for $10 \mathrm{~min}$ at $10000 \mathrm{rpm}$. Pellets were washed twice and resuspended in MRS without glucose and containing $\mathrm{pH}$ indicator bromecresol purple. Then inoculated $(2 \%, \mathrm{vol} / \mathrm{vol})$ in $10 \mathrm{ml}$ inulin medium, glucose solution was used as positive control while suspended cells in basal medium containing $\mathrm{pH}$ indicator bromecresol purple was used as a negative one. After $24 \mathrm{~h}$ incubation at $37^{\circ} \mathrm{C}$ under anaerobic conditions, the color change from purple to yellow was recorded as positive fermentation results compared with the positive and negative controls (Hedberg et al., 2008).

The anticancer effect of inulin fermentation product of probiotic bacteria on Caco-2 cells

Probiotic isolates were selected for further investigation to evaluate their ability to induce apoptosis in Caco-2 cells. Probiotic isolates were grown in MRS basal medium containing $10 \mathrm{gm} / \mathrm{L}$ filter sterilized inulin solution at $37{ }^{\circ} \mathrm{C}$ for $24 \mathrm{~h}$ anaerobically (Barry et al., 1995). For in vitro preparation of the cell-free filtrate, cultured bacterial cells were centrifuged at $11,000 \times \mathrm{g}$ for $30 \mathrm{~min}$. then supernatant was filtered using a 0.22 $\mu \mathrm{m}$ syringe filter and was stored at $4{ }^{\circ} \mathrm{C}$ until use. 
Human Colorectal Carcinoma cell line, Caco2, was purchased from VACSERA (Egyptian company for production of vaccines and sera - tissue culture unit). The cells were cultured in RPMI-1640 medium supplemented with 10\% ( $\mathrm{vol} / \mathrm{vol}$ ) fetal bovine serum and incubated at $37^{\circ} \mathrm{C}$ in a $\mathrm{CO}_{2}$ incubator. The Caco-2 monolayers were at $90 \%$ confluence prepared in 6 -well plates, then washed twice with phosphate buffered saline (PBS) (pH 7.4). Each supernatant was mixed with the RPMI-1640 medium in concentration 50\% (1 ml supernatants: $1 \mathrm{ml}$ RPMI-1640 medium). MRS containing RPMI1640 medium was used as negative controls and doxorubicin HCL $(0.4 \mu \mathrm{g} /$ $\mathrm{ml}$ RPMI1640 medium) as positive control. The treatments were added to each well of the plates and incubated for $24 \mathrm{~h}$ under aseptic conditions in humidified atmosphere and $5 \% \mathrm{CO}_{2}$ at $37^{\circ} \mathrm{C}$. DNA-binding dyes Acridine orange (AO) and ethidium bromide (EB) double staining were carried out to detect the apoptosis in Caco-2 cells.

Acridine orange/ethidium bromide (AOEB) stock solution (100x): acridine orange, 15 $\mathrm{mg}$; ethidium bromide, $50 \mathrm{mg}$ dissolved in $1 \mathrm{ml}$ $95 \%$ ethanol and QS to a total volume of $45 \mathrm{ml}$ in purified water. Aworking solution of (AO-EB) was prepared by diluting a $1-\mathrm{ml}$ aliquot of the stock solution into $100 \mathrm{ml}$ PBS. After $24 \mathrm{~h}$ incubation of cells with the supernatant, the media were discarded and $100 \mu \mathrm{l}$ of the dye mix working solution was added to each well. The dye was immediately (fast uptake) examined by fluorescence inverted microscope (LEICA DMI3000 B) filter I3 at 200x magnification recording changes in morphology and color changes of the nucleus because of each supernatant, each assay was carried out in triplicate. The cells were divided into three categories as follows: living cells (normal green nucleus), early apoptotic (bright green nucleus with condensed or fragmented chromatin) and late apoptotic (orangestained nuclei with chromatin condensation or fragmentation) (Attari et al., 2009).

\section{Preparation of freeze-dried probiotic powders}

This was carried out according to Zárate \& Nader-Macias (2006) with slight modifications, each probiotic bacterium was cultivated in MRS broth; then, $10 \mathrm{ml}$ of each culture was inoculated into $250 \mathrm{ml}$ of sterile MRS-broth and incubated at $37^{\circ} \mathrm{C}$. Cells were harvested by centrifugation $\left(\times 7000 \mathrm{~g}, 10 \mathrm{~min}, 4^{\circ} \mathrm{C}\right)$, washed twice with sterile PBS and then resuspended in $4 \mathrm{ml}$ of $10 \%$ sterile reconstituted skimmed milk. This suspension was fractioned into 2 bottles $(50 \mathrm{ml})$ and frozen at $-20^{\circ} \mathrm{C}$. Frozen media were lyophilized under vacuum for $8 \mathrm{~h}$ (ilShinBioBase freeze dryer) and freeze-dried powders were placed aseptically into empty gelatin capsules $(50 \mathrm{mg} /$ capsule approximately). Samples were obtained from each culture before and after freeze-drying and the numbers of viable cells were enumerated.

\section{Storage stability of the freeze-dried powders}

Gelatin capsules containing $20 \mathrm{mg}$ of lyophilized powder in each capsule were stored at two temperatures: room temperature and $4^{\circ} \mathrm{C}$, inside sterile containers containing silica-gel desiccants and stored under darkness. Duplicate samples were taken from storage at $0,1,2,4,10$ and 12 weeks for testing of probiotic viability by plate counting. The lyophilized powders were rehydrated in $1 \mathrm{ml}$ of saline solution $(0.9 \% \mathrm{NaCl})$ and these suspensions were serially 10 -fold diluted in sterile peptone-water, all colonies were enumerated after incubation of plates at $37^{\circ} \mathrm{C}$ for $48 \mathrm{~h}$. Results were expressed as log of CFU/capsule of lyophilized powder. The weight of freeze dried microorganisms was determined by the difference between full and empty capsules (Jalali et al., 2012).

\section{Results}

Depending on a previous study for selection of the LAB isolates with probiotic properties and inulin fermentation ability, of all isolates five strains (Lactobacillus paraplantarum strain S143, L. pentosus strain P2-3, L. plantarum strain J12, L. gasseri strain F., and $L$. Retire strain IRT) showed remarkable probiotic properties, thus they were selected for continuing anticancer examinations and with details presenting their characteristics.

The anticancer effect of inulin fermentation product of probiotic bacteria on Caco-2 cells

Since one of the most desired strategies in cancer therapy is induction of apoptosis in tumor cells, to analyze the incidence of apoptosis in Caco-2 cancer cells and prove the anticancer effect of inulin fermentation product by the selected five probiotic bacteria, the Caco-2 were exposed to $50 \%$ filtrate supernatant of inulin fermentation product by the tested probiotic bacteria after $24 \mathrm{~h}$ of incubation to visualize apoptosis using the Acridine orange / Ethidium bromide double staining and observation by fluorescent microscopy. 
DNA-binding dyes AO and EB were utilized for the detection of apoptotic cells morphology. Acridine orange is taken up by both viable and nonviable cells and emits green fluorescence if intercalated into double stranded nucleic acid (DNA) or red fluorescence if bound to single stranded nucleic acid (RNA). Ethidium bromide is taken up only by nonviable cells and emits red fluorescence by intercalation into DNA. The cells were divided into three categories as follows: living cells (normal green nucleus), early apoptotic (bright green nucleus with condensed or fragmented chromatin) and late apoptotic (orange-stained nuclei with chromatin condensation or fragmentation).
Results showed that none of the apoptosis related signs were observed in the negative control cells, they appear as viable cells with uniform bright green nuclei with organized structure. While positive control treated cells are orange-stained nuclei with chromatin condensation or fragmentation.

The Morphological features of apoptosis can be seen in Fig. 1 cells treated by inulin fermentation product of the probiotic (L. paraplantarum strain S143, L. pentosus strain P2-3 and L. plantarum strain J12) there were shrunken cells having yellow nuclei with condensed or fragmented chromatin; these apoptosis characteristics belonged to late apoptosis stage.

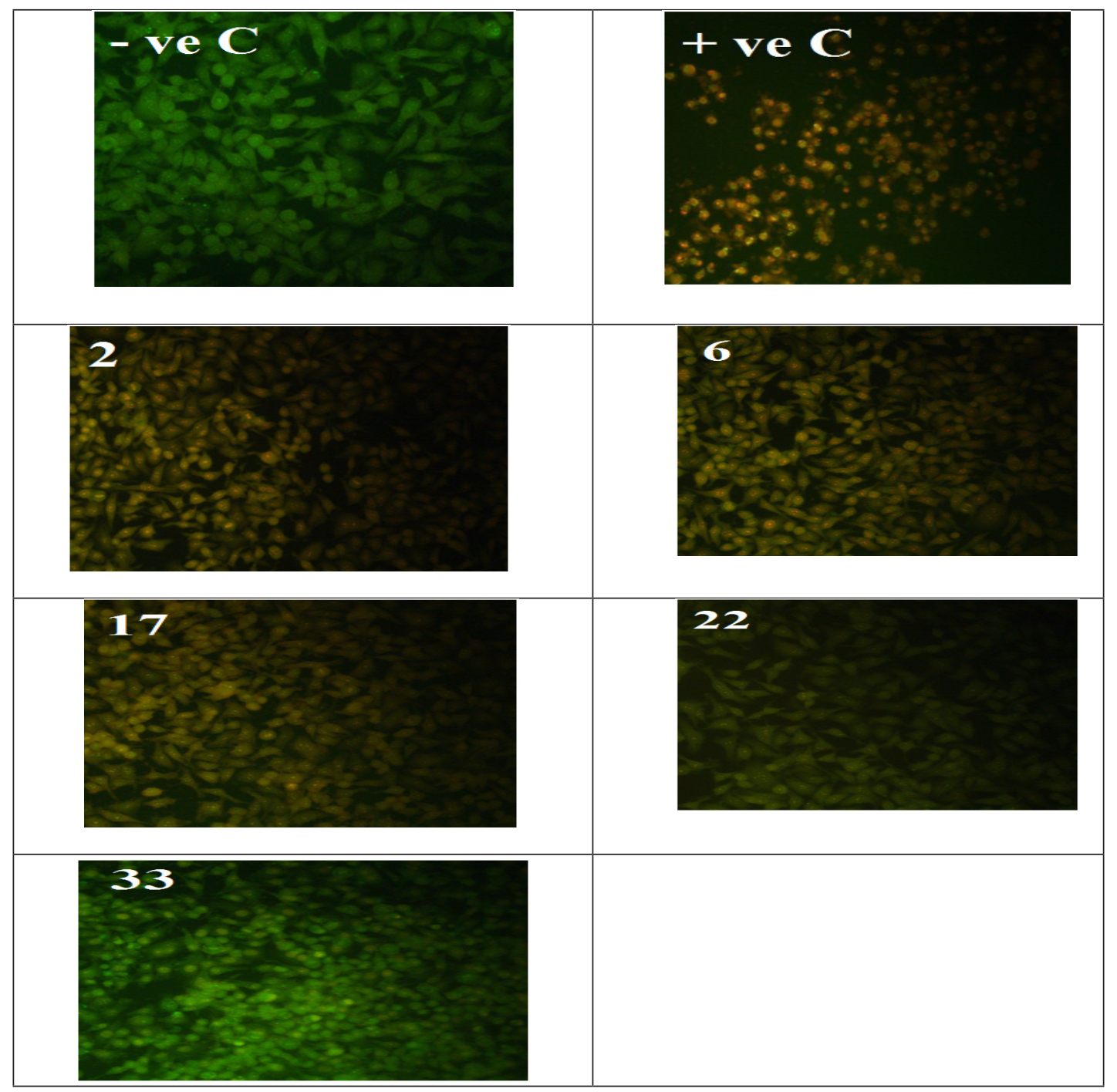

Fig. 1. Fluorescent microscope pic. of Caco-2 cell line treated with filtrate supernatant of inulin fermentation product by the tested probiotic bacteria after $24 \mathrm{~h}$ of incubation to visualize apoptosis using the Acridine orange / Ethidium bromide double staining (-ve C: negative control, +ve C: positive control, 2: $L$. paraplantarum strain S143, 6: L. pentosus strain P2-3, 17: L. plantarum strain J12, 22: L. gasseri strain F and 33: $L$. reuteristrain IRT).

Egypt. J. Microbiol Vol. 52 (2017) 
Also in Fig. 1 cells treated with inulin fermentation product of the probiotic (L. gasseri strain F and $L$. reuteri strain IRT) show green shrinking cells which still have intact membranes but have started to undergo DNA cleavage with perinuclear chromatin condensation visible as bright green patches. These distinctive signs of apoptosis belonged to early apoptosis stage.

\section{Storage of capsules}

According to the data presented in the Tables 1 and 2, when the probiotic cultures were freezedried in skimmed milk as a cryoprotectant, their viable counts decreased about $0-0.2 \log \mathrm{CFU}$ when compared to the viable counts before freeze drying. After 12 weeks storage of the freeze dried probiotic bacteria at room temperature their viable counts showed slight decrease about $1-1.4 \mathrm{log}$ $\mathrm{CFU} /$ capsule when compared to their viable counts immediately after freeze drying.

Finally, the lyophilized probiotic bacteria conserved higher viability after 12 weeks of storage at $4^{\circ} \mathrm{C}$ as their viable count decreased about $0.5-1.1 \log \mathrm{CFU} /$ capsule.

TABLE 1. Survival of the probiotic cultures after freeze-drying and 12 weeks storage at room temperature.

\begin{tabular}{|c|c|c|c|c|c|c|c|}
\hline \multirow{2}{*}{ Isolate No. } & \multirow{2}{*}{$\begin{array}{l}\text { Counts before } \\
\text { freeze drying } \\
\log \text { CFU/ml }\end{array}$} & \multicolumn{6}{|c|}{$\begin{array}{l}\text { Viable cell counts ( } \log \mathrm{CFU} / \text { capsule) } \\
\text { after freeze drying during storage at room temperature }\end{array}$} \\
\hline & & $0 \mathrm{w}$ & $1 \mathrm{w}$ & $2 \mathrm{w}$ & $4 \mathrm{w}$ & $10 \mathrm{w}$ & $12 \mathrm{w}$ \\
\hline L. paraplantarum strain S143 & 12.4 & 12.3 & 11.9 & 11.9 & 11.6 & 11.4 & 11.1 \\
\hline L. pentosus strain $\mathrm{P} 2-3$ & 12.3 & 12.3 & 12.2 & 12.2 & 12.1 & 11.3 & 11.3 \\
\hline L. plantarum strain J12 & 12.5 & 12.4 & 12.3 & 12 & 11.7 & 11.6 & 11.4 \\
\hline L. gasseri strain F & 12.6 & 12.4 & 12.3 & 12.2 & 12.1 & 11.9 & 11.3 \\
\hline L. reuteri strain IRT & 12.4 & 12.4 & 12.3 & 12 & 11.9 & 11.7 & 11 \\
\hline
\end{tabular}

TABLE 2. Survival of the probiotic cultures after freeze-drying and 12 weeks storage at $4^{\circ} \mathrm{C}$.

\begin{tabular}{|c|c|c|c|c|c|c|c|}
\hline \multirow{2}{*}{ Probiotics } & \multirow{2}{*}{$\begin{array}{l}\text { Counts before } \\
\text { freeze drying } \\
\log \text { CFU/ml }\end{array}$} & \multicolumn{6}{|c|}{$\begin{array}{l}\text { Viable cell counts (log } \mathrm{CFU} / \text { capsule) } \\
\text { after freeze drying during storage at } 4^{\circ} \mathrm{C}\end{array}$} \\
\hline & & $\mathbf{0} \mathbf{w}$ & $1 \mathrm{w}$ & $2 \mathbf{w}$ & $4 w$ & $10 \mathrm{w}$ & $12 \mathrm{w}$ \\
\hline L. paraplantarum strain S143 & 12.4 & 12.3 & 12.4 & 12.1 & 11.9 & 11.9 & 11.6 \\
\hline L. pentosus strain P2-3 & 12.3 & 12.3 & 12.3 & 12.2 & 12.1 & 12 & 11.3 \\
\hline L. plantarum strain J12 & 12.5 & 12.4 & 12.3 & 12.2 & 12.2 & 11.7 & 11.7 \\
\hline L. gasseri strain F & 12.6 & 12.4 & 12.5 & 12.4 & 12.3 & 12.1 & 11.9 \\
\hline L. reuteri strain IRT & 12.4 & 12.4 & 12.3 & 12.1 & 12 & 11.7 & 11.3 \\
\hline
\end{tabular}

\section{Discussion}

In each year, about 1.2 million new cases of colorectal cancer are diagnosed all over the world (Jemal et al., 2010). At present, the therapy for colon cancer includes surgery, radiation therapy, chemotherapy, as well as immunotherapy and gene therapy. Surgical resection is generally applied to early stage of cancer, which likely leads to bowel dysfunction. Quite a few patients suffered the postoperative recurrence and metastasis and were required to undergo chemotherapy (Lim et al., 2013). At present, the drugs used for chemotherapy not only inhibit the cancer cell growth, but also destruct the normal cells. Therefore, exploring effective therapies that are specifically sensitive to cancer cells not to normal cells is particularly important. Probiotic microbes have been associated with a variety of health benefits including enhanced immune performance, suppression of tumor cells and protection against colon cancer (Suzuki et al., 2008). Health promoting effects of probiotic bacteria is found to be strain dependent and their positive effectin colon cancer may also vary from one strain to another (Sadeghi-Aliabadi et al., 2014).

A prebiotic is a selectively fermented ingredient that permits specific changes, in the 
composition and/or activity in the gastrointestinal microbiota that confers benefits upon the host wellbeing and health (Vandenplas, 2016).Prebiotics are non-digestible carbohydrates acting as a nutritive substrate to stimulate the growth and metabolism of probiotic bacteria (Ghouri et al., 2014). Whereas probiotics introduce exogenous bacteria in the colonic microbiota, prebiotics aim to modulate the endogenous luminal microflora by selectively stimulating the growth of health-promoting bacteria already present in the colon. For example, different non-digestible carbohydrates, such as galactooligosaccharides, showed the potential to increase the number of bifidobacteria and subsequently the production of short chain fatty acids (SCFAs) in healthy volunteers (Bouhnik et al., 2004).

Butyrate has received much attention as a potential chemopreventive agent (Abrahamse et al., 1999). Butyrate act as an energy source for non-transformed cells, and also reduce the survival of tumor cells by inducing apoptosis and differentiation as well as inhibiting proliferation. These mechanisms may play an important role in the reduction and / or inhibition of promotion and progression of cancer development (Sengupta et al., 2006).

Apoptosis is programmed cell death that plays an important role in controlling cell numbers. Therefore, the regulation of cell proliferation and death can be one of cancer treatment strategies (Zhong et al., 2014). Probiotic bacteria can regulate cell apoptosis and proliferation. LAB isolated from infant faeces inhibited colon cancer cell proliferation through direct adhesion to cancer cells and production of SCFA (Thirabunyanon \& Hongwittayakorn, 2013). The anti-proliferative effect of L. acidophilus and L. plantarum on colon cancer cells via induction of apoptosis has been previously reported by several researchers (Nami et al., 2014).

In this study, using the $\mathrm{EB} / \mathrm{AO}$ stain results showed that after $24 \mathrm{~h}$ of Caco- 2 cell line exposure to filter sterilized inulin fermentation supernatant of the probiotics (L. paraplantarum strain S143,L. pentosus strain $\mathrm{P} 2-3$ and $L$. plantarum strain J12) displayed morphological feature of late apoptosis; while those of (L. gasseri strain F and L. reuteristrain IRT) showed early apoptosis stage.

These results are similar to previous results obtained by Haghshenas et al. (2014), they investigated acceptable cytotoxic effect of the secreted metabolites of Lactococcus lactis subsp. Lactis 44Lac against all of the treated HT29 cancer cell lines. Cytotoxic assessments through flow cytometry and fluorescent microscope proved that apoptosis is the main cytotoxic mechanism for the secreted metabolites.

Also, Haghshenas et al. (2015) studied the effect of L. plantarum 17C on HT-29 cell viability, HT-29 cells were exposed to the supernatant produced during the late stationary growth phase of L. plantarum $17 \mathrm{C}$ and analyzed by fluorescent microscope and found a significant number of apoptotic cells after $24 \mathrm{~h}$ of incubation with $50 \mu \mathrm{g} / \mathrm{ml}$ of L. plantarum $17 \mathrm{C}$ supernatant.

Soltan et al. (2015) reported that the supernatants of L. acidophilus ATCC 4356 and L. casei ATCC 39392 decreased CaCo-2 cell proliferarion and increased cell apoptosis.

The utilization of prebiotic substances in combination with probiotic strains (synbiotics) is an important topic for industrial purposes. In functional foods, prebiotic substances have a double role: they improve probiotic survival during storage in foods, and when reconstituted in the bowel, they act to enhance the digestive process (Roberfroid, 2007). Therefore, the study of new synbiotic formulations is particularly anticipated (Casiraghi et al., 2007). One of the main benefits of synbiotics is to increase the persistence of the probiotic bacteria in the gastrointestinal tract (Rastall \& Maitin, 2002).

In this study, inulin was selected as a prebiotic for the symbiotic formulation with the freezedried powders of the five selected probiotic for the production of gelatin capsules.

While they are well-known in the food industry, the enthusiasm in probiotics has spiked latelyto the pharmaceutical industry, the administration of pharmaceutical formulations containing such viable health promoting bacteria, these pharmabiotics need to provide their benificial effects until the end of shelf life (Broeckx et al., 2016).

As probiotic utilization shifted from nutritional supplement to medicinal treatment, product stability is a source of concern (Barrons $\&$ Tassone, 2008). The quality of probiotic relies 
greatly on their viability, which is a fundamental fulfillment to colonize the human large intestine (Lahtinen et al., 2005).

To be effective, at least $10^{8}-10^{9} \mathrm{CFU}$ viable probiotics per daily dose should be consumed and therefore maintained alive in commercial products (Desfosses-Foucault et al., 2012). One of the significant issues concerning the formulation of probiotics and pharmabiotics is their loss of viability after processing and during storage. Many factors, such as temperature, oxygen level, moisture level, pressure and dosage formulation have an influence on the viability of probiotics and thus their healthpromoting activity. Although some immunerelated effects can also be achieved by non-living probiotics or their isolated compounds (Lebeer et al., 2010), the presence of a sutable amount of viable bacteria in the probiotic formulation is an important criterion for health claims (Hill et al., 2014). To enhance long-term stability of probiotics, it is important to preserve them in a dried form, in which the water content is decreased (Vesterlund et al., 2012).

Subsequently, suitable probiotic microbes and fitting vectors must be chosen. Unfortunately, many studies found that the high number of lactobacilli/ bifidobacteria in many commercial probiotic products was not accomplished as claimed in the product data, particularly in the dried form of probiotic products: more than $67 \%$ of dried powder or granule products distributed in Taiwan markets contained LAB lower than 106CFU/ml, and half of the product brands contained no viable LAB (Lin et al., 2006). In the European countries, $30 \%$ of dried probiotic supplement brands available in the market contained no viable bacteria (Temmerman et al., 2002). Similar observations on products in the UK have been made by Hamilton-Miller \& Shah (2002).

The industrial application of LAB depends on concentration and conservation technologies that are needed to ensure the long-term stability of cultures in terms of viability and functional activity (Li et al., 2010). It is basic, both technologically and economically to increase the viability of probiotic culture during drying and storage for long periods (Carvalho et al., 2004). There are many mechanisms that allow us to keep the viability of the bacteria over time, cryopreservation and lyophilization being the most usable (Palmfeldt et al., 2003). Moreover, freeze-drying and subsequent storage decrease microbial viability since the drying expose microbes to an extra stress. Different species show different degrees of survival to freeze-drying (Font et al., 1983). To limit this damage, cryoprotectant substances are generally utilized. Skimmed milk can avoide harm by balancing the cell membrane and providing a protective layer for the cells (Carvalho et al., 2004). For most LAB cultures of commercial enthusiasmin the dairy industry, skim milk powder is chosen as drying medium,since it (i) Avoid cellular injury by balancing out the cell membrane constituents (Selmer-Olsen et al., 1999), (ii) Makes a porous structure in the freezedried product that makes rehydration easier, and (iii) Contains proteins that provide a protective covering for the cells (Abadias et al., 2001).

In the present study, the effect of storage on the viability of the freeze-dried powder of the five probiotics in gelatin capsules stored in sterile containers containing silica-gel desiccants were studied at room temperature and at $4^{\circ} \mathrm{C}$. The viable count of the lyophilized probiotics showed a slight reduction when stored at $4^{\circ} \mathrm{C}$. While at room temperature the viable counts of the probiotics showed a higher reduction.

These results agree with the results obtained by Rathnayaka (2013) they studied the effect of lyophlization on viability and probiotic properties of a probiotic microbial mixture containing Lactobacillus rhamnosus and L. plantarum with UHT milk, sucrose, sorbitol and trehalose during six-month storage at $4^{\circ} \mathrm{C}$ was also studied. They prepared five types of mixed probiotic cultures: as microbial mixture in PBS, UHT milk, UHT milk added with sucrose, UHT milk added with sorbitol and UHT milk added with trehalose. Better survival of microorganisms after lyophlization was shown in all tried bacterial mixtures except the bacterial mixture in phosphate buffered saline. Highest survival was appeared in the bacterial mixture with UHT milk. According to the results of the Shigella inhibitory assay, probiotic properties of microbes has not been changed by lyophlization or long-term storage.

Also, Gisela et al. (2014) determined the ideal levels of incorporation of different cryoprotectants (skim milk, sucrose and trehalose) in the freezedrying process of Lactobacillus plantarum, and obtained the ideal concentrations of cryoprotective agents: $24.06 \%$ milk powder, $6.22 \%$ sucrose, $5.63 \%$ trehalose. 
Moreover, Jalali et al. (2012) analyzed the impact of differant formulations of cryoprotectant media containing skim milk, trehalose and sodium ascorbate on the survival rate of probiotic bacteria during lyophlization at different storage temperatures for preparation of a capsule containing the probiotics Lactobacillus paracaseisub sp. tolerance and Lactobacillus delbrueckiisub sp. Bulgaricus, and found that with no cryoprotectant, small number of bacteria survived, but they maintained higher viability after lyophlization in media with the cryoprotectants. Skim milk in water resulted in an increased viability after freezedrying. Media with a combination of trehalose and skim milk maintained a higher percentage of viable bacteria, up to $82 \%$. In general, a higher number of viable cells was found in capsules containing freeze-dried bacteria with sodium ascorbate after 3 months of storage. After this period, a marked decline was observed in all samples stored at $23^{\circ} \mathrm{C}$ compared to those stored at $4^{\circ} \mathrm{C}$. The greatest survival rate (about $72-76 \%$ ) was observed with media containing $6 \%$ skim milk, $8 \%$ trehalose and $4 \%$ sodium ascorbate.

\section{Conclusion}

In conclusion, the use of probiotics in enhancing the gut microflora of human shows signs of becoming a success. This study showed promising results to exploit the freeze-dried powders of the strains supplemented with inulin as probiotics mixture with anti-cancer effects for therapeutic purposes. However, more in vitro/in vivo investigations should be conducted before this preparation is introduced as potential anti-cancer therapeutics.

\section{References}

Abadias, M., Benabarre, A., Teixid N., Usall, J., and Vinäs, I. (2001) Effect of freeze-drying and protectants on viability of the biocontrol yeast Candida sake. International Journal of Food Microbiology, 65, 173-182.

Abrahamse, S.L., Pool-Zobel, B.L. and Rechkemmer, G. (1999) Potential of short chain fatty acids to modulate the induction of DNA damage and changes in the intracellular calcium concentration by oxidative stress in isolated rat distal colon cells. Carcinogenesis, 20, 629-34.

Abushelaibi, A., Al-Mahadin, S., El-Tarabily, K., Shah, N.P. and Ayyash, M. (2017) Characterization of potential probiotic lactic acid bacteria isolated from camel milk. LWT. Food Science and Technology, 79, 316-325.

Attari, F., Sepehri, H., Delphi, L. and Goliaei, B. (2009) Apoptotic and necrotic effects of pectic acid on rat pituitary GH3/B6 Tumor Cells. Iranian Biomed. J. 13(4), 229-236.

Barrons, R.. and Tassone, D. (2008) Use of Lactobacillus probiotics for bacterial genitourinary infections in women : A Review. Clinical Therapeutics, 30(3),.

Barry, J.L., Hoebler, C. and Macfarlane, G.T. (1995) Estimation of the fermentability of dietary fibre in vitro: A European interlaboratory study. Br. J. Nutr. 74, 303-322.

Biondi, A., Fisichella, R., Fiorica, F., Malaguarnera, M. and Basile, F. (2012) Food mutagen and gastrointestinal cancer. Eur. Rev. Med. Pharmacol. Sci. 16,1280-2.

Bouhnik, Y., Raskine, L., Simoneau, G., Vicaut, E., Neut, C. and Flourie, B. (2004) The capacity of nondigestible carbohydrates to stimulate fecal bifidobacteria in healthy humans: a double-blind, randomized, placebo-controlled, parallel-group, doseresponse relation study. Am. J. Clin. Nutr. 80, 1658-64.

Broeckx, G., Vandenheuvel, D., Claes, I.J.J., Lebeer, S. and Kiekens, F. (2016) Drying techniques of probiotic bacteria as an important step towards the development of novel pharmabiotics. International Journal of Pharmaceutics, 505, 303-318.

Buigues, C., Fernández-Garrido, J., Pruimboom, L., Hoogland, A.J., Navarro-Martínez, R., MartínezMartínez, M., Verdejo, Y., Mascarós, M.C., Peris, C. and Cauli, O. (2016) Effect of a prebiotic formulation on frailty syndrome: A randomized, double-blind clinical trial. Int. J. Mol. Sci. 17(6).

Carvalho, A.S., Silva, J., Ho, P., Teixeira, P., Malcata, F.X. and Gibbs, P. (2004) Relevant factors for the preparation of freeze-dried lactic acid bacteria. International Dairy Journal, 14, 835-847.

Casiraghi, M.C., Canzi, E., Zanchi, R., Donati, E. and Villa, L. (2007) Effects of a synbiotic milk product on human intestinal ecosystem. J. Appl. Microbiol. 103, 499-506. 
Commane, D., Hughes, R., Shortt, C. and Rowland, I. (2005) The potential mechanisms involved in the anti-carcinogenic action of probiotics. Muta. Res. 591, 276-89.

Cross, A.J., Ferrucci, L.M., Risch, A., Graubard, B.I., Ward, M.H. and Park, Y. (2010) Large prospective study of meat consumption and colorectal cancer risk: An investigation of potential mechanisms underlying this association. Cancer Res. 70, 2406-14.

Desfosses-Foucault, E., Dussault-Lepage, V., Le Boucher, C., Savard, P., La Pointe, G. and Roy, D. (2012) Assessment of probiotic viability during Cheddar cheese manufacture and ripening using propidiummonoazide-PCR quantification. Frontiers in Microbiology, 3.

Faghfoori, Z., Gargari, B.P., Gharamaleki, A.S., Bagherpoure, H. and Khosroushahi, A.Y. (2015) Cellular and molecularmechanisms of probiotics effects on colorectal cancer. Journal of Functional Foods, 18, 463-472.

FAO/WHO (2006) Probiotics in food: Health and nutritional properties and guidelines for evaluation. FAO food nutrition paper 85. Rome: World Health Organization and Food and Agriculture Organization of the United Nations.

Font, G., Savoy, G., Pesce, A. and Oliver, G. (1983) Comparative study of the efficiency of some additives in protecting lactic acid bacteria against Freeze-Drying. Cryobiology, 20, 560-566.

Ghouri, Y.A., Richards, D.M., Rahimi, E.F., Krill, J.T., Jelinek, K.A. and DuPont, A.W. (2014) Systematic review of randomized controlled trials of probiotics, prebiotics, and synbiotics in inflammatory bowel disease. Clin. Exp. Gastroenterol. 7, 473-87.

Gisela, G., Leonardo, A.E., Lucia, P., Rodrigo, V., Eduard, G. and Angeles, C.M. (2014) Enhacement of the viability of Lactobacillus plantarum during the preservation and storage process based on the response surface methodology. Food and Nutrition Sciences, 5, 1746-1755.

Globocan (2012) international Agency for Research on Cancer "Estimated Cancer incidence, mortality and prevalence worldwide in 2012".http://globean,iarc.fr/ pages/facts_sheets_population.aspx.2012.

Haggar, F.A. and Boushey, R.P. (2009) Colorectal cancer epidemiology: incidence, mortality, survival, and risk factors. Clin. Colon Rect. Surgery, 22, 191-197.

Haghshenas, B., Abdullah, N., Nami, Y., Radiah, D., Rosli, R. and YariKhosroushahi, A. (2014) Different effects of two newly-isolated probiotic Lactobacillus plantarum $15 \mathrm{HN}$ and Lactococcus lactis subsp. Lactis 44Lac strains from traditional dairy products on cancer cell lines. Anaerobe, 30, 51-59.

Haghshenas, B., Nami, Y., Haghshenas, M., Abdullah, N., Rosli, R., Radiah, D. and Khosroushahi, A.Y. (2015) Bioactivity characterization of Lactobacillus strains isolated from dairy products. Microbiology Open, 4(5), 803-813.

Hamilton-Miller, J. M. and Shah, S. (2002) Deficiencies in microbiological quality and labeling of probiotic supplements. International Journal of Food Microbiology, 72 (1-2), 175-176.

Hedberg, M., Hasslöf, P., Sjöström, I., Twetman, S., and Stecksén-Blicks, C. (2008) Sugar fermentation in probiotic bacteria - an in vitro study. Oral Microbiology Immunology, 23, 482-485.

Hill, C., Guarner, F., Reid, G., Gibson, G.R., Merenstein, D.J. and Pot, B. (2014) Expert consensus document. The international scientific association for probiotics and prebiotics consensus statement on the scope and appropriate use of the term probiotic. Nat. Rev. Gastroenterol. Hepatol. 11(8), 506-514.

Jalali, M., Abedi, D., Varshosaz, J., Najjarzadeh, M., Mirlohi, M. and Tavakoli, N. (2012) Stability evaluation of freeze-dried Lactobacillus paracasei subsp. tolerance and Lactobacillus delbrueckii subsp. bulgaricus in oralcapsules. Research in Pharmaceutical Sciences, 7(1), 31-36.

Jemal, A., Siegel, R., Ward, E., Murray, T., Smigal, C. and Thun, M.J. (2006) Cancer statistics. CA, Cancer J. Clin. 56, 106-130.

Jemal, A., Center, M.M., DeSantis, C. and Ward, E.M (2010) Global patterns of cancer incidence and mortality rates and trends. Cancer Epidemiology Biomarkers \& Prevention, 19(8), 1893-1907.

Lahtinen, S.J., Gueimonde, M., Ouwehand, A.C., Reinikainen, J.P. and Salminen, S.J. (2005) Probiotic bacteria may become dormant during storage. Appl. Environ. Microbio. 171, 1662-1663. 
Lebeer, S., Vanderleyden, J. and De Keersmaecker, S.C.J. (2010) Host interactions of probiotic bacterial surface molecules: Comparison with commensals and pathogens. Nat. Rev. Microbiol. 8, 171-184.

Li, H.P., Lu, M.J., Guo, H.F., Li, W. and Zhang, H.P. (2010) Protective Effect of Sucrose on the membrane properties of Lactobacillus casei Zhang subjected to freeze-drying. Journal of Food Protection, 73, 715719.

Lim, M., Hussain, Z., Howe, A., Storey, R., Petty, D., Haselden, J., Sebag-Montefiore, D. and Alexander, D. (2013) The oncological outcome after right hemicolectomy and accuracy of CT scan as a preoperative tool for staging in right sided colonic cancers. Colorectal Disease, 15(5), 536-543.

Lin, W.H., Hwang, C.F., Chen, L.W., and Tsen, H.Y. (2006) Viable counts, characteristic evaluation for commercial lactic acid bacteria products. Food Microbiology, 23 (1), 74-81.

Ljungh, Á. And Wadström, T. (2006) Lactic acid bacteria as probiotics. Curr Issues Intest. Microbiol. 7, 73-89.

Munjal, U., Glei, M., Pool-Zobel, B. L. and Scharlau, D. (2009) Fermentation products of inulin-type fructans reduce proliferation and induce apoptosis in human colon tumour cells of different stages of carcinogenesis. British Journal of Nutrition, 102, 663-671.

Nami, Y., Abdullah, N., Haghshenas, B., Radiah, D., Rosli, R. and Khosroushahi, A.Y. (2014) Assessment of probiotic potential and anticancer activity of newly isolated vaginal bacterium Lactobacillus plantarum 5BL. Microbiology and Immunology, 58(9), 492502.

Orlando, A. and Russo, F. (2013) Intestinal microbiota, probiotics and human gastrointestinal cancers, $J$. Gastrointest. Cancer, 44, 121-131.

Palmfeldt, J., Adsträom, P.R. and Hahn-Häagerdal, B. (2003) Optimisation of initial cell concentration enhances freeze-drying tolerance of Pseudomonas chlororaphis. Cryobiology, 47, 21-29.

Rastall, R.A. and Maitin, V. (2002) Prebiotics and synbiotics: towards the next generation. Curr. Opin. Biotechnol. 13, 490-496.

Rathnayaka, R.M.U.S.K. (2013) Effect of freeze - drying on viability and probiotic properties of a mixture of probiotic bacteria. ARPN Journal of Science and Technology, 3(11), 1074- 1078.

Roberfroid, M. (2007) Prebiotics: The concept revisited. J. Nutr. 137, 830S-837S.

Saad, N., Delattre, C., Urdaci, M., Schmitter, J.M. and Bressollier, P. (2013) An overview of the last advances in probiotic and prebiotic field. LWT-Food Science and Technology, 50, 1-16.

Sadeghi-Aliabadi, H., Mohammadi, F., Fazeli, H. and Mirlohi, M. (2014) Effects of Lactobacillus plantarum A7 with probiotic potential on colon cancer and normal cells proliferation in comparison with a commercial strain. Iranian Journal of Basic Medical Sciences, 7, 815-819.

Selmer-Olsen, E., Birkeland, S.E. and Sêrhaug, T. (1999) Effect of protective solutes on leakage from and survival of immobilized Lactobacillus subjected to drying, storage and rehydration. Journal of Applied Microbiology, 87, 429-437.

Sengupta, S., Muir, J.G. and Gibson, P.R. (2006) Does butyrate protect from colorectal cancer? $J$. Gastroenterol. Hepatol. 21, 209-218.

SoltanDallal, M.M., Mojarrad, M., Baghbani, F., Mardaneh, J. and Salehipour, Z. (2015) Effects of probiotic Lactobacillus acidophilus and Lactobacillus caseion colorectal tumor cells activity (CaCo-2). Archives of Iranian Medicine, 18(3), 167-172.

Steina, K., Borowickia, A., Scharlaua, D., Schettlera, A., Scheub, K., Obstb, U. and Gleia, M. (2012)Effects of synbiotic fermentation products on primary chemoprevention in human colon cells. Journal of Nutritional Biochemistry, 23, 777-784.

Stewart, B.W. and Kleihues, P. (2003) Editors. World cancer report. Lyon: IARC press; 2003. p. 57.

Suzuki, C., Kimoto-Nira, H., Kobayashi, M., Nomura, M., Sasaki, K. and Mizumachi, K. (2008) Immunomodulatory and cytotoxic effects of various Lactococcus strains on the murine macrophage cell line J774.1. Int. J. Food Microbiol. 123, 159-165.

Temmerman, R., Pot, B., Huys, G. and Swings, J. (2002) Identification and antibiotic susceptibility of bacterial isolates from probiotic products. International Journal of Food Microbiology, 81(1), 1-10. 
Thirabunyanon, M. and Hongwittayakorn, P. (2013) Potential probiotic lactic acid bacteria of human origin induce antiproliferation of colon cancer cells via synergic actions in adhesion to cancer cells and short-chain fatty acid bioproduction. Applied Biochemistry and Biotechnology, 169 (2), 511-525.

Vandenplas, Y. (2016) Probiotics and prebiotics in infectious gastroenteritis: Best practice \& research. Clinical Gastroenterology, 30, 49-53.

Vesterlund, S., Salminen, K. and Salminen, S. (2012) Water activity in dry foods containing live probiotic bacteria should be carefully considered: A case study with Lactobacillus rhamnosus GG in flaxseed. Int. J. Food Microbiol. 157, 319-321.

Vijaya Kumar, B., Vijayendra, S.V.N., and Reddy, O. V.S. (2015) Trends in dairy and non-dairy probiotic products - a review. Journal of Food Science and Technology, 52 (10), 6112e6124. http://dx.doi. org/10.1007/s13197-015-1795-2.

WHO (2014) Cancer worldwide. In World Cancer report (Stewart BW, Wild CP(eds.). Lyon, France, International Agency for Research on cancer, pp. 16-69.

Zárate, G. and Nader-Macias, M. (2006) Viability and biological properties of probiotic vaginal lactobacilli after lyophilization and refrigerated storage into gelatin capsules. Process Biochemistry, 41, 1779-1785.

Zhong, L., Zhang, X. and Covasa, M. (2014) Emerging roles of lactic acid bacteria in protection against colorectal cancer. World Journal of Gastroenterology, 20 (24), 7878-7886.

\section{الجمع بين بريبايوتيك وخليط من البروبيوتيك بكتريا المجففه بالتجميد لتطوير سينبيوتيك التوبي يحفز الموت المبرمجج في خلايا القولون البشري البريك بكريانية

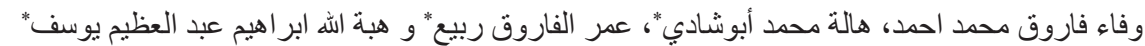

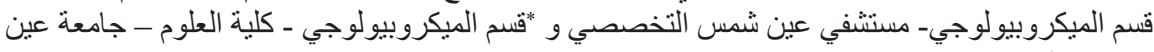

